\title{
How Long Does a Cough Last? Compar- ing Patients' Expectations With Data From a Systematic Review of the Literature
}

Mark H. Ebell, MD, MS 1,2

Jerold Lundgren, $B S^{3}$

Surasak Youngpairoj, MD, MPH

'Department of Epidemiology and Biostatistics, College of Public Health, The University of Georgia, Athens, Georgia

${ }^{2}$ Institute for Evidence-Based Practice in the Health Professions, College of Public Health, The University of Georgia, Athens, Georgia

${ }^{3}$ Franklin College, The University of Georgia, Athens, Georgia

${ }^{4}$ College of Public Health, The University of Georgia, Athens, Georgia

Ti

MORE ONLINE

www.annfammed.org
AC Annals Journal Club selection; see inside back cover or http://www.annfammed.org/AJC/.

Conflicts of interest: authors report none.

\section{CORRESPONDING AUTHOR}

Mark H. Ebell, MD, MS

University of Georgia Health Science

Campus

233 Miller Hall, Buck Rd

Athens, GA 30602

ebell@uga.edu

\begin{abstract}
PURPOSE We hypothesized that antibiotic overuse for acute cough illness (ACI) is in part due to a mismatch between patients' expectations and the natural history of $\mathrm{ACl}$.

METHODS We performed a population-based random digit dialing survey of 493 adults in Georgia to determine their expectations regarding the duration of $\mathrm{ACl}$. We also performed a systematic review of observational studies and the placebo or untreated control groups of randomized controlled trials to determine the duration of $\mathrm{ACl}$ from the published medical literature. We included studies of otherwise healthy adults with undifferentiated $\mathrm{ACl}$, no clear bacterial cause, data on at least 1 cough outcome, and at least 1 week of follow-up.
\end{abstract}

RESULTS The mean duration of cough in the published literature was 17.8 days. Survey respondents reported a median duration of 5 to 7 days and a mean duration of 7.2 to 9.3 days depending on the specific scenario. Patients expecting a longer duration of illness were more likely to be white, female, and have selfreported asthma or chronic lung disease. Independent predictors of the belief that antibiotics are always helpful included nonwhite race $(\mathrm{OR}=1.82,95 \% \mathrm{Cl}$, 1.14-2.92), some college education or less $(\mathrm{OR}=2.08,95 \% \mathrm{Cl}, 1.26-3.45)$, and previous antibiotics for $\mathrm{ACl}(\mathrm{OR}=2.20,95 \% \mathrm{Cl}, 1.34-3.55)$.

CONCLUSIONS There is a mismatch between patients' expectations regarding the duration of $\mathrm{ACl}$ and the actual duration based on the best available evidence. Efforts to reduce inappropriate antibiotic use should target this discrepancy.

Ann Fam Med 2013;11:5-13. doi:10.1370/afm.1430.

\section{INTRODUCTION}

$\Lambda$ cute cough illness $(\mathrm{ACI})$ is one of the most common reasons that patients seek care in the outpatient primary care setting. In 2006 there were more than 3 million outpatient visits in the United States for a chief complaint of cough and more than 4.5 million outpatient visits with a final diagnosis of "acute bronchitis or bronchiolitis." Overall, ACI accounts for approximately $2 \%$ to $3 \%$ of visits to outpatient physicians. ${ }^{1}$

Although typically a self-limited condition caused by viruses, many patients seek care and request antibiotics for ACI. Even though the rate of antibiotic prescribing for ACI is decreasing (from $65 \%$ of visits for $\mathrm{ACI}$ in 1996 to $50 \%$ in 2006), it remains too high. ${ }^{2}$ In addition, an increasing proportion of prescriptions are for broad-spectrum antibiotics, such as azithromycin and respiratory quinolones. ${ }^{2}$

We hypothesized that patients may request antibiotics in part because of a mismatch between their expectations regarding the duration of $\mathrm{ACI}$ and the natural history of the condition. A single study in children aged less than 4 years found that parents underestimated the duration of cough 
in their children. ${ }^{3}$ Although a previous systematic review examined the natural history of $\mathrm{ACI}$ in children, ${ }^{4}$ we were unable to identify a previous systematic review of the natural history of $\mathrm{ACI}$ in otherwise healthy adults. We were also unable to identify any published descriptions of patients' expectations regarding the duration of $\mathrm{ACI}$ in adults. We undertook the current study to explore this issue further, specifically to determine whether such a mismatch in fact exists and to better understand predictors of a belief in the efficacy of antibiotics for ACI. A better understanding of these issues could help clinicians develop educational and public health strategies to reduce inappropriate demand for antibiotics.

This study was approved by the Human Subjects Committee of the University of Georgia.

\section{METHODS}

\section{Systematic Review of the Natural History of $\mathrm{ACI}$}

We used the following strategy to search the MEDLINE database on February 1, 2011, with subsequent monthly searches to identify any additional studies through November 2011. The strategy is similar to that used by Hay and colleagues in their study of the natural history of cough in children ${ }^{4}$ :

("acute bronchitis"[Text Word] OR "acute bronchitis" [MeSH Terms] OR "respiratory tract infections" $[\mathrm{MeSH}$ Terms] OR "respiratory tract infection"[Text Word] OR "chest cold"[Text Word] OR "chest cold"[MeSH Terms])

This search yielded 258,693 abstracts. Adding limits of English or German, abstract, and human reduced the number to 84,536 . Limiting the search to adults resulted in 39,006 abstracts. Because the focus of our study was the natural history of undifferentiated acute respiratory tract infection with cough in otherwise healthy adults, we added terms to exclude studies of sinusitis, pneumonia, tuberculosis, vaccinations, asthma, allergies, anthrax, chronic lung disease, or cystic fibrosis. The final search strategy returned 478 abstracts.

Additionally, we performed the following search: (("duration"[Title/Abstract]) AND ("acute cough"[Title/ Abstract] OR "acute bronchitis"[Title/Abstract]). So doing yielded 26 studies, 6 of which were potentially relevant and had not been found previously by the above search strategy, and 2 of which were ultimately included. We also retrieved all clinical trials identified in the reference list of the most recent Cochrane review of antibiotics for acute bronchitis, because the untreated placebo group in a clinical trial may be relevant to our study. Abstracts and unpublished studies were not used.
We reviewed each abstract in tandem and, where necessary, performed a detailed review of the full text to identify studies that met our inclusion criteria. All studies were reviewed by the principal investigator, an experienced researcher and family physician (M.H.E.), each study was also reviewed by one of the other investigators (one of whom was also a physician). Specifically, we included prospective cohort studies and controlled trials (where there was an untreated group of patients) that studied community-dwelling adult outpatients without serious pulmonary comorbidity. We selected only those studies that predominantly recruited patients with undifferentiated ACI, as well as studies of "acute bronchitis." Included studies had to gather data on the presence or severity of individual ACI symptoms or a validated cough severity score for at least 1 week.

We excluded studies set in the hospital, studies of adults with serious chronic respiratory illness, and studies of patients for whom there was a clearly suspected cause of cough (eg, pneumonia, sinusitis, anthrax, or influenza), because our goal was to study undifferentiated $\mathrm{ACI}$. We also excluded studies in which patients were inoculated with a particular virus or of patients whose cough was induced pharmacologically, as well as studies of specific groups (ie, swimmers, mountain climbers, postoperative patients, postintubation patients, smokers). Finally, we excluded studies of prevention of acute respiratory infection, studies in which the predominant symptom was sore throat or rhinitis, and studies of postinfectious or chronic cough.

Data regarding study design and study findings were abstracted in tandem by 2 of the investigators. Discrepancies were resolved by consensus. In clinical trials, we used data for only those patients who did not receive antibiotic, herbal, or antiviral therapy (ie, the control group). The total days with cough were directly reported by some studies and determined from examination of survival curves in others. Some studies reported the mean days of cough before and after enrollment in the study. If a study did not report the mean days of cough before enrollment but did specify a maximum number of days of symptoms before enrollment (ie, "acute cough for 7 or fewer days"), we used one-half of that number as an estimate of the mean days cough before enrollment. For example, 1 day if up to 2 days were specified, 4 days if up to 7 days were specified, and 7 days if up to 14 days were specified.

Regarding quality assessment of included studies, we included only studies that gathered data prospectively for at least 1 week and had at least $80 \%$ follow-up (confirmed by independent review of 2 researchers). Quality of included studies was not otherwise assessed; 
such study design characteristics as allocation concealment, masking, and randomization method were not relevant because we included only patients from the placebo group.

\section{Survey of the General Population Regarding ACI}

We used the Georgia Poll, a random digit dialing survey of approximately 500 Georgia residents aged 18 years and older that is conducted twice each year by the Survey Research Center of the University of Georgia. Participants were asked about 1 of 6 randomly selected versions of the following scenario:

Suppose that you get sick and the main symptom is a cough. You are coughing up yellow mucus and have a slight fever (100.5 degrees). You are not taking any medicine for the cough. About how long do you expect that it will take from the time you first feel sick until the time where you feel well and the cough is gone?

We created the 6 scenarios by altering the 3 types of cough (yellow sputum, green sputum, or dry cough) and whether the patient had a fever. We then asked participants the extent to which they believed that antibiotics were effective for the ACI described in the scenario using the following question: "Which of the following best describes how you feel about antibiotics for this illness?" Possible responses included the following: "antibiotics would always be helpful and would always reduce how long I am sick"; "antibiotics would usually be helpful and would probably reduce how long I am sick"; "antibiotics would sometimes be helpful and might reduce how long I am sick"; "antibiotics would rarely be helpful and would be unlikely to reduce how long I am sick"; "antibiotics would never be helpful, and would not reduce how long I am sick."

Finally, participants were asked whether they had ever been prescribed an antibiotic for an acute cough illness, whether they had asthma or chronic lung disease, and whether they had any chronic medical conditions. Basic demographic data (age, educational attainment, marital status, race, residence, income) were also obtained.

\section{Analysis}

Results are primarily descriptive; weighted means were calculated for mean days of cough and mean days of productive cough. Ranges are reported; standard deviation was not provided by 2 studies, making DerSimonian Laird random effects meta-analysis or a formal measure of heterogeneity such as the $I^{2}$ statistic impossible to calculate.

To analyze the survey findings, we used a Pearson $\chi^{2}$ test for bivariate analysis of categorical variables, Student's $t$ test for comparison of 2 means, and analysis of variance (ANOVA) for comparisons of more than 2 means. Logistic regression was used to identify independent predictors of belief in the efficacy of antibiotics, and linear regression was used to identify variables independently associated with the predicted duration of acute cough illness. Stata 11.1 (StataCorp, LP) was used for statistical analyses.

\section{RESULTS}

\section{Systematic Review of the Natural History of $\mathrm{ACl}$}

We identified 19 studies with between 23 and 1,230 patients that met our inclusion criteria. Characteristics of included studies are summarized in Table 1. Followup ranged from 7 days to 2 months. Most studies explicitly excluded patients who were pregnant, had a clear indication for antibiotics (ie, pneumonia), had chronic lung disease, or had another serious chronic condition. When reported, the mean age ranged from 29.7 to 44.0 years. Eight studies took place in Europe, 7 in the United States, 3 in Russia, and 1 in Kenya. Outcomes reported by at least 2 studies included clinical cure, percentage coughing, percentage complete remission, and percentage unable to work; mean days of any cough, daytime cough, nighttime cough, and productive cough, and cough severity using the 20 -point Bronchitis Severity Score. The Bronchitis Severity Score is a validated measure of symptoms of acute cough illness that rates the severity of $5 \mathrm{symp}$ toms (cough, sputum, rales/rhonchi, chest pain during coughing, and dyspnea) from 0 to 4 points each, with higher scores indicating greater illness severity.

Results of the meta-analysis for the mean duration of any cough and subsets of cough are shown in Table 2. The weighted mean duration of any cough was 17.8 days (range $=15.3$ to 28.6 days), and for productive cough was 13.9 days (range $=13.3$ to 17.4 days).

The range for the percentage of patients who were clinically cured 8 days after the onset of symptoms was $20 \%$ to $73 \% \cdot{ }^{15,16,21}$ Because the outcome of clinical cure was defined differently by different studies, we did not attempt to pool these data. The percentage with cough 8 days after onset was more consistent $(86.4 \%$ to $95.0 \%$ ), likely because the 3 studies reporting this outcome were funded by the same sponsor, and thus used similar outcome definitions. ${ }^{15,16,19}$ The percentage with cough at the end of the study was $91 \%$ at 16 days in 1 study, ${ }^{11} 73 \%$ at 17 days in a second, ${ }^{13}$ and $82 \%$ at 21 days in a third. ${ }^{8}$ Finally, 8 days after the onset of symptoms, 3 studies reported that the percentage of patients unable to work as a result of their ACI ranged from $33 \%$ to $52 \% .^{15,21,22}$

The Bronchitis Severity Score at different points 
at the onset of cough is shown in Supplemental Table 1, available at http://annfammed.org/content/11/1/5/

ppl/DC1. Figure 1 graphs the weighted mean Bronchitis Severity Score score against days from onset of symptoms. A simple linear regression shows that the score would equal 0 approximately 24 days after the onset of symptoms and approximately 1 at 18 days after onset of symptoms, consistent with the data regarding the mean duration of cough (17.8 days).

\section{Survey of the General Population Regarding ACI}

Of 1,131 eligible persons contacted by the Georgia Poll, 493 responded to the survey questionnaire (43.6\%). The final sample was $36.9 \%$ male $68.0 \%$ were

Table 1. Characteristics of Studies Included in the Systematic Review

\begin{tabular}{|c|c|c|c|c|c|c|}
\hline $\begin{array}{l}\text { First Author, } \\
\text { Year }\end{array}$ & $\begin{array}{l}\text { Duration of } \\
\text { Follow-up }\end{array}$ & Setting & Inclusion Criteria & $\begin{array}{l}\text { Mean } \\
\text { Age, y }\end{array}$ & $\begin{array}{c}\text { Male } \\
\%\end{array}$ & Country \\
\hline Stott, $1976^{5}$ & $13 d$ & 3 Group practices & $\begin{array}{l}\text { Aged }>14 \text { y with cough and purulent } \\
\text { sputum for } \leq 1 \text { wk }\end{array}$ & NR & NR & Wales \\
\hline $\begin{array}{l}\text { Williamson, } \\
1984^{6}\end{array}$ & $2 \mathrm{mo}$ & $\begin{array}{l}2 \text { Academic family medi- } \\
\text { cal centers, University of } \\
\text { Missouri }\end{array}$ & $\begin{array}{l}\text { Adults aged } 21 \text { to } 65 \text { y with cough } \\
\text { and sputum as prominent com- } \\
\text { plaints, who also had concurrent } \\
\text { URTI, rhonchi, or history of fever }\end{array}$ & 35 & 34 & $\begin{array}{l}\text { United } \\
\text { States }\end{array}$ \\
\hline $\begin{array}{l}\text { Brickfield, } \\
1986^{7}\end{array}$ & $7 \mathrm{~d}$ & $\begin{array}{l}\text { Academic family medicine } \\
\text { center, Washington, DC }\end{array}$ & $\begin{array}{l}\text { Adults aged } 18 \text { to } 65 \text { y with clinically } \\
\text { diagnosed acute bronchitis (lower } \\
\text { respiratory infection with sputum } \\
\text { production) of }<2 \text { wk }\end{array}$ & 32.5 & 58 & $\begin{array}{l}\text { United } \\
\text { States }\end{array}$ \\
\hline Dunlay, $1987^{8}$ & $14 d$ & $\begin{array}{l}\text { Academic family medicine } \\
\text { center, Chelsea, Mchigan }\end{array}$ & Adults with productive cough & 44 & 42 & $\begin{array}{l}\text { United } \\
\text { States }\end{array}$ \\
\hline Scherl, $1987^{9}$ & 2 wk & $\begin{array}{l}\text { Outpatient medical clinic, } \\
\text { University of Kentucky }\end{array}$ & $\begin{array}{l}\text { Patients aged } \geq 12 \text { y with cough and } \\
\text { purulent sputum for }<2 \mathrm{wk}\end{array}$ & 31 & 26 & $\begin{array}{l}\text { United } \\
\text { States }\end{array}$ \\
\hline Verheij, $1994^{10}$ & $11 \mathrm{~d}$ & 22 General practices & Adult with cough and purulent sputum & 41 & 42 & Netherlands \\
\hline $\begin{array}{l}\text { Hueston, } \\
1994^{11}\end{array}$ & $7 \mathrm{~d}$ & $\begin{array}{l}2 \text { Family practice centers, } \\
\text { Kentucky and Wisconson }\end{array}$ & $\begin{array}{l}\text { Adults aged } 18 \text { to } 65 \text { y with produc- } \\
\text { tive cough }<30 \mathrm{~d} \text { and no signs } \\
\text { pneumonia }\end{array}$ & 36.9 & 30 & $\begin{array}{l}\text { United } \\
\text { States }\end{array}$ \\
\hline King, $1996^{12}$ & $14-18 d$ & $\begin{array}{l}3 \text { Academic family medicine } \\
\text { centers, North Carolina }\end{array}$ & $\begin{array}{l}\text { Aged }>8 y \text {, cough and sputum pro- } \\
\text { duction, and onset within } 2 \text { wk }\end{array}$ & 38.2 & 36 & $\begin{array}{l}\text { United } \\
\text { States }\end{array}$ \\
\hline $\begin{array}{l}\text { Littenberg, } \\
1996^{13}\end{array}$ & $7 \mathrm{~d}$ & $\begin{array}{l}\text { Dartmouth Hitchcock Medi- } \\
\text { cal Center }\end{array}$ & $\begin{array}{l}\text { Adults with nonspecific bronchitis or } \\
\text { acute cough }<4 \text { wk }\end{array}$ & 33.7 & 39 & $\begin{array}{l}\text { United } \\
\text { States }\end{array}$ \\
\hline $\begin{array}{l}\text { Matthys, } \\
2000^{14}\end{array}$ & 4 wk & 40 Outpatient clinics & $\begin{array}{l}\text { Adults with acute bronchitis ( }<5 \mathrm{~d}, \geq 4 \\
\text { nightly awakenings due to cough); } \\
\text { otherwise in good mental and } \\
\text { physical condition }\end{array}$ & 39 & 46 & Poland \\
\hline $\begin{array}{l}\text { Matthys, } \\
2003^{15}\end{array}$ & $7 \mathrm{~d}$ & $\begin{array}{l}\text { Outpatient clinics, totaling } \\
36 \text { physicians }\end{array}$ & $\begin{array}{l}\text { Adults with clinically diagnosed acute } \\
\text { bronchitis, }<48 \text { h of symptoms, and } \\
\text { BSS } \geq 5\end{array}$ & 39.9 & 32 & Germany \\
\hline $\begin{array}{l}\text { Chuchalin, } \\
2005^{16}\end{array}$ & $7 \mathrm{~d}$ & $\begin{array}{l}\text { Urban primary care outpa- } \\
\text { tient clinics }\end{array}$ & $\begin{array}{l}\text { Adults with clinically diagnosed acute } \\
\text { bronchitis }<48 \mathrm{~h} \text { and } \mathrm{BSS} \geq 5^{\mathrm{a}}\end{array}$ & 35.9 & 37 & Russia \\
\hline Little, $2005^{17}$ & $21 \mathrm{~d}$ & $\begin{array}{l}37 \text { General practice } \\
\text { physicians }\end{array}$ & $\begin{array}{l}\text { Patients aged } \geq 3 \text { y }(83 \%>6 \text { y) with } \\
\text { primary symptom of cough and } \geq 1 \\
\text { other lower respiratory symptoms }\end{array}$ & 38 & NA & England \\
\hline $\begin{array}{l}\text { Kemmerich, } \\
2007^{18}\end{array}$ & $11 \mathrm{~d}$ & 23 Outpatient clinics & $\begin{array}{l}\text { Adults with clinical diagnosis of acute } \\
\text { bronchitis and onset of bronchial } \\
\text { mucus production in past days, as } \\
\text { well as } \geq 10 \text { coughing fits on previ- } \\
\text { ous day }\end{array}$ & 43.5 & 38 & Germany \\
\hline $\begin{array}{r}\text { Matthys, } \\
2007^{19}\end{array}$ & $7 \mathrm{~d}$ & $\begin{array}{l}3 \text { Academic polyclinics, } \\
\text { Moscow }\end{array}$ & $\begin{array}{l}\text { Adults aged } 18 \text { to } 65 \text { y with clinically } \\
\text { diagnosed acute bronchitis, }<48 \text { h, } \\
\text { and BSS }>5\end{array}$ & 37.4 & 21 & Russia \\
\hline Nduba, $2008^{20}$ & $14 \mathrm{~d}$ & Public clinic, Nairobi & Adult with productive cough $<2$ wk & 29.7 & 38 & Kenya \\
\hline $\begin{array}{l}\text { Matthys, } \\
2008^{21}\end{array}$ & $7 \mathrm{~d}$ & $\begin{array}{l}6 \text { Outpatient clinics, } \\
\text { Moscow }\end{array}$ & $\begin{array}{l}\text { Adults with acute bronchitis, BSS } \geq 5 \text {, } \\
\text { symptoms }<48 \mathrm{~h}\end{array}$ & 37 & 21 & Russia \\
\hline $\begin{array}{l}\text { Matthys, } \\
2010^{22}\end{array}$ & $7 \mathrm{~d}$ & 18 Centers & $\begin{array}{l}\text { Adults with acute bronchitis }<48 \text { h, } \\
\text { BSS } \geq 5\end{array}$ & 38.5 & NR & Ukraine \\
\hline Butler, $2010^{23}$ & $28 d$ & 387 General practitioners & $\begin{array}{l}\text { Patients aged } \geq 18 \mathrm{y} \text {, with acute or } \\
\text { worsened cough as predominant } \\
\text { symptom or clinical signs of lower } \\
\text { respiratory tract infection, duration } \\
\text { up to } 28 \mathrm{~d}\end{array}$ & & 36 & $\begin{array}{l}13 \text { Euro- } \\
\text { pean } \\
\text { countries }\end{array}$ \\
\hline
\end{tabular}

BSS = Bronchitis Severity Score; NR = not reported; URTI = upper respiratory tract infection.

a Scores range from $0-20$, with higher scores indicating greater severity of illness. 
white, 27.6\% African-American, 1.4\% Hispanic, and the remainder multiracial or other. Regarding education, $44.0 \%$ were college graduates, and all but $6.5 \%$ were high school graduates. Regarding age, $26.7 \%$ were aged between 18 and 44 years, $45.7 \%$ were between 45 and 64 years, and $27.6 \%$ were 65 years or older. Based on a comparison with 2010 census figures for Georgia, the respondents were somewhat older,

\begin{tabular}{|lcc|}
\hline \multicolumn{2}{|c|}{$\begin{array}{l}\text { Table 2. Mean Days of Any Cough, Daytime } \\
\text { Cough, Nighttime Cough, and Productive Cough }\end{array}$} \\
\hline $\begin{array}{l}\text { Outcome } \\
\text { First Author, Year }\end{array}$ & $\begin{array}{c}\text { Patients } \\
\text { Studied }\end{array}$ & $\begin{array}{c}\text { Days of Cough } \\
\text { Mean (SD) }\end{array}$ \\
\hline Any cough & & $17.8^{\mathrm{a}}$ \\
Williamson, 1984 & 32 & 28.6 \\
Nduba, 2008 & 275 & $15.3(4.3)$ \\
Scherl, 1987 & 15 & 17.8 \\
Little, 2005 & 269 & $21.3(5.8)$ \\
Butler, 2010 & 1,230 & $17.3(6.6)$ \\
Daytime cough & & $12.7^{\mathrm{a}}$ \\
Stott, 1976 & 103 & $10.3(3)$ \\
Verheij, 1994 & 69 & $16.2(3.2)$ \\
Nighttime cough & & $10.4^{\mathrm{a}}$ \\
Stott, 1976 & 84 & $8.9(3.1)$ \\
Verheij, 1994 & 69 & $12.2(2.7)$ \\
Productive cough & & $13.9^{\mathrm{a}}$ \\
Williamson, 1984 & 32 & 13.7 \\
Scherl, 1987 & 15 & 17.4 \\
Verheij, 1994 & 69 & $13.3(3)$ \\
\hline
\end{tabular}

Note: standard deviation shown only if reported by the original study. a Weighted mean.

better educated, and more likely to be female than the general population but had a similar racial distribution. We believe they reflect a typical population seeking care for ACI in the United States.

Approximately $20 \%$ of respondents to the Georgia Poll did not respond to the question regarding expected duration of cough in the scenario. Respondents to this question were younger ( 54 vs 63 years, $P<.001)$ and more likely to be female $(24 \%$ vs $16 \%$, $P=.03)$. The predicted mean duration of ACI among all respondents $(n=395)$ ranged from 6.9 to 9.3 days depending on the scenario, and from 6.5 to 9.2 days for respondents who had no self-reported history of asthma or chronic lung disease $(\mathrm{n}=352)$. A histogram of the distribution of estimates by patients without chronic respiratory disease is shown in Figure 2. The median estimated duration of an episode was 5 to 7 days, depending on the scenario. There was a trend to ascribe a longer duration of illness to episodes characterized by green sputum rather than yellow sputum or dry cough ( 8.7 vs 7.6 days, $P=.06)$ and by episodes without fever ( 7.5 vs 8.5 days, $P=.08$ ).

In the bivariate analysis, a longer predicted duration of ACI was associated with previous use of antibiotics for ACI, self-reported chronic lung disease, female sex, white race, and lower educational attainment (Table 3). A linear regression identified white race, self-reported asthma or chronic lung disease, and female sex as independent predictors of a longer predicted duration of ACI.

We also examined the association between patient characteristics and belief in antibiotic efficacy, classified as either "antibiotics are

Figure 1. Weighted mean of the Bronchitis Severity Score by the number of days from the onset of symptoms.

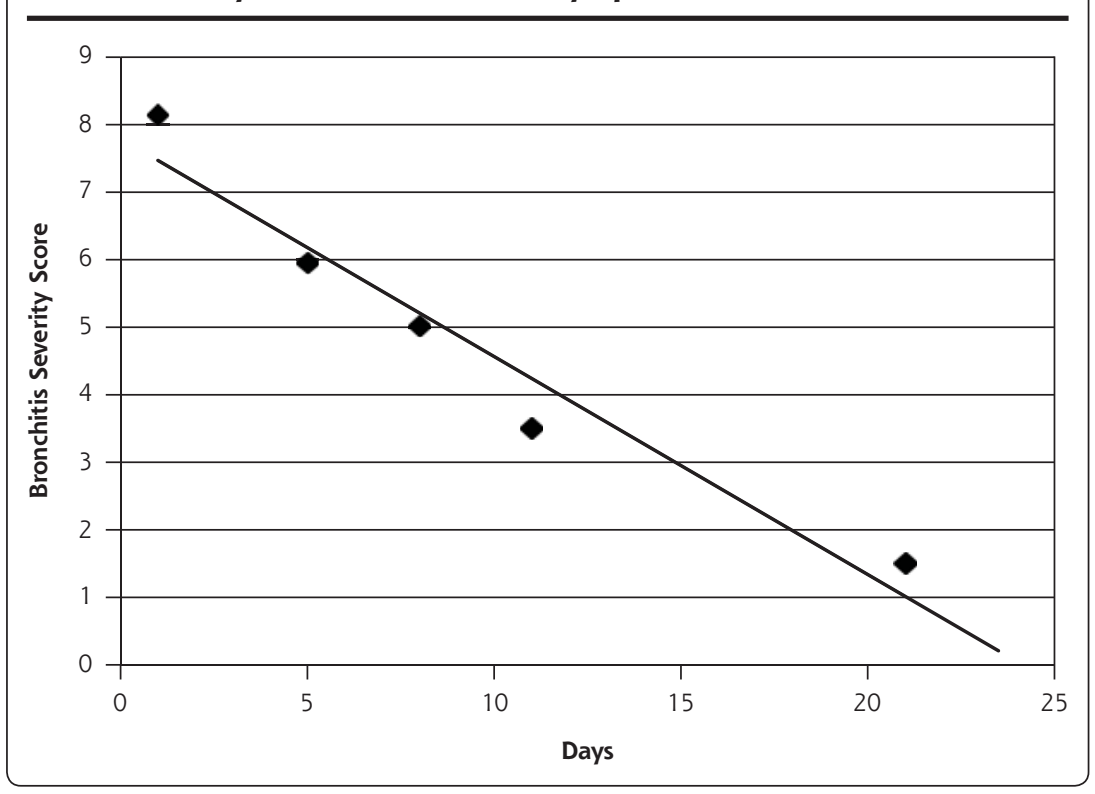

always helpful" or "antibiotics are always or usually helpful." Bivariate predictors of the belief that antibiotics are "always helpful" for acute respiratory tract infections included lower income, less education, not being married, nonwhite race, a self-reported history of asthma or chronic lung disease, and previous prescriptions of antibiotics for ACI. Bivariate predictors of the belief that antibiotics are "always or usually helpful" included less education, nonwhite race, and previous prescriptions of antibiotics for ACI (Table 4). In the logistic regression (Table 5 ), independent predictors of the belief that antibiotics are "always helpful" included nonwhite race $(\mathrm{OR}=1.82,95 \% \mathrm{CI}, 1.14-2.94)$, 
some college education or less $(\mathrm{OR}=2.08,95 \% \mathrm{CI}$, 1.26-3.45), and previous antibiotics for $\mathrm{ACI}(\mathrm{OR}=2.2$, 95\% CI, 1.34-3.55).

\section{DISCUSSION}

We found a significant mismatch between expectations of community-dwelling adults regarding the mean duration of a typical ACI (6.5 to 9.2 days) and the actual duration of ACI from the medical literature (approximately 18 days). The largest and best single study to date, a European collaborative study of 1,230 patients, ${ }^{23}$ reported results similar not only to those of our study regarding mean duration of $\mathrm{ACI}$ (17.3 days) but also to the other 4 studies reporting this outcome in the literature (range 15.3 to 28.6 days). ${ }^{6,9,17,20}$ Furthermore, studies using the validated Bronchitis Severity Score also found that symptoms persisted beyond 2 weeks for many patients (Figure 1).

The specific scenario (yellow sputum vs green sputum vs dry cough, and fever or no fever) had relatively little influence on the predicted duration of symptoms, with the difference between scenarios about 1 day. A shorter duration was predicted by men and by nonwhite respondents, whereas a longer duration was reported by those with self-reported asthma or chronic lung disease. This finding is not surprising, as patients with an acute exacerbation of asthma or chronic lung disease complicated by an acute respiratory tract infection often have a more protracted course. They also may be more aware of their symptoms and may have more episodes, thus providing a more accurate estimate of duration.

The mismatch between patients' expectations and reality for the natural history of acute cough illness has important implications for antibiotic prescribing. If a patient expects that an episode of ACI should last about 6 or 7 days, it makes sense that they might seek care for that episode and request an antibiotic after 5 or 6 days. Furthermore, if they begin taking an antibiotic 7 days after the onset of symptoms, they may begin to feel better 3 or 4 days later, with the episode fully resolving 10 days later. Although this outcome may reinforce the mistaken idea that the antibiotic worked, it is merely a reflection of the natural history of ACI.

Other researchers have found that previous experiences with antibiotics, having a chronic medical condition, and believing antibiotics are helpful for viruses

\section{Figure 2. Predicted duration of acute cough illness (ACI) in days by a random sample of Georgia adults.}

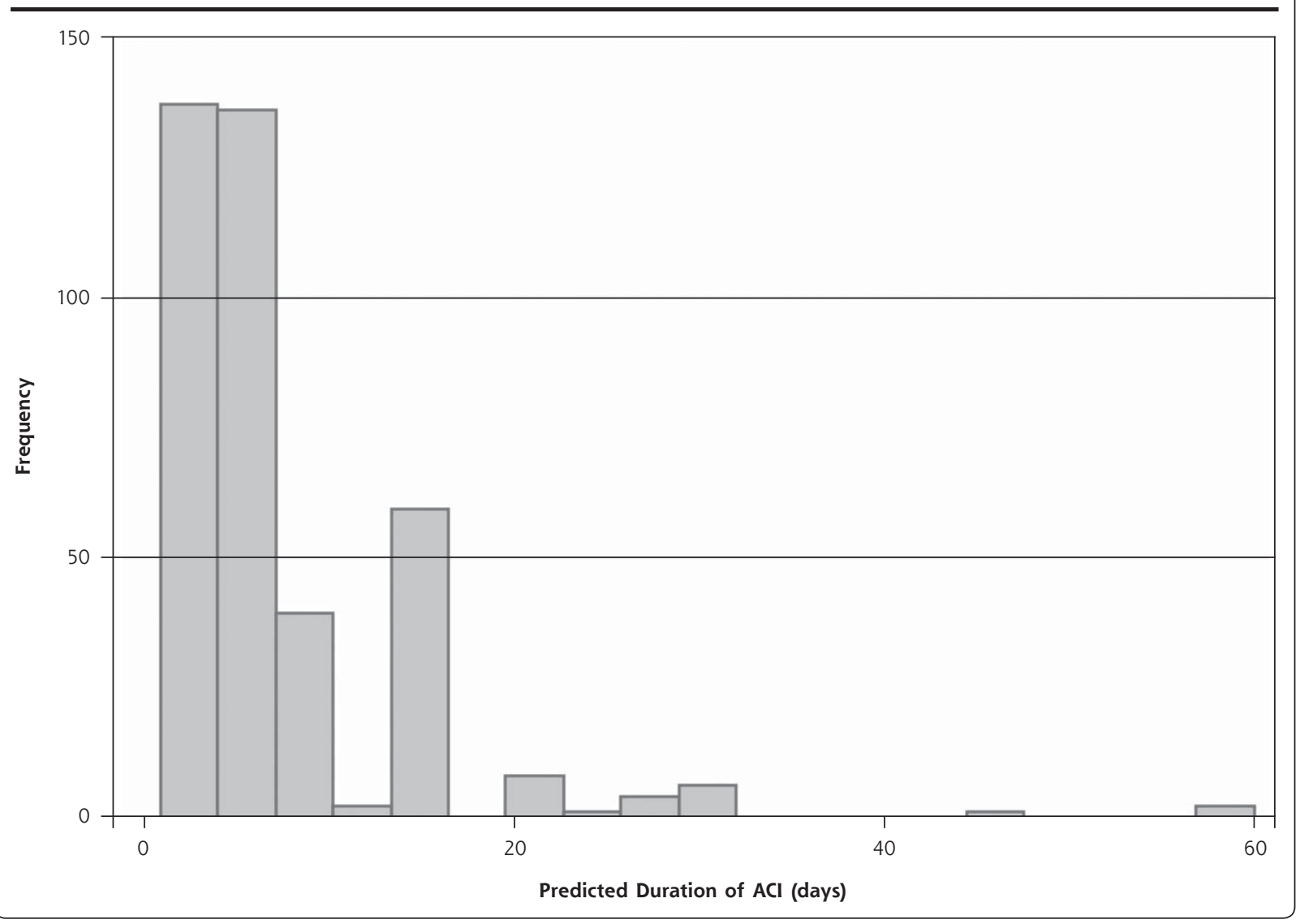


Table 3. Predicted Days of Duration of Acute Cough Illness by Vignette, Illness Characteristics, and Patient Characteristics

\begin{tabular}{|c|c|c|c|}
\hline Characteristics & No. & $\begin{array}{l}\text { Predicted Duration } \\
\text { Mean }(95 \% \mathrm{Cl})\end{array}$ & $\begin{array}{c}P \\
\text { Value }\end{array}$ \\
\hline \multicolumn{4}{|l|}{ Vignettes } \\
\hline Yellow sputum and fever & 58 & $7.2(5.8-8.6)$ & .45 \\
\hline Yellow sputum and no fever & 66 & $7.9(6.1-9.7)$ & \\
\hline Green sputum and fever & 69 & $8.3(6.8-9.8)$ & \\
\hline Green sputum and no fever & 53 & $9.3(7.5-11.1)$ & \\
\hline Dry cough and fever & 80 & $6.9(5.6-8.2)$ & \\
\hline Dry cough and no fever & 69 & $8.4(6.0-10.7)$ & \\
\hline \multicolumn{4}{|l|}{$\mathrm{ACl}$ characteristics } \\
\hline Green sputum & 122 & $8.7(7.6-9.9)$ & .06 \\
\hline Other & 273 & $7.6(6.7-8.4)$ & \\
\hline Yellow sputum & 124 & $7.6(6.4-8.7)$ & .25 \\
\hline Other & 271 & $8.1(7.2-9.0)$ & \\
\hline Dry cough & 149 & $7.6(6.3-8.9)$ & .21 \\
\hline Other & 246 & $8.1(7.3-9.0)$ & \\
\hline Fever & 207 & $7.5(6.6-8.3)$ & .08 \\
\hline No fever & 188 & $8.5(7.3-9.6)$ & \\
\hline \multicolumn{4}{|l|}{$\begin{array}{l}\text { Self-reported previous use } \\
\text { of antibiotics for } \mathrm{ACl}\end{array}$} \\
\hline Yes & 246 & $8.7(7.7-9.7)$ & .004 \\
\hline No & 149 & $6.7(5.9-7.6)$ & \\
\hline \multicolumn{4}{|l|}{$\begin{array}{l}\text { Self-reported asthma or } \\
\text { chronic lung disease }\end{array}$} \\
\hline Yes & 43 & $10.9(7.1-14.6)$ & .002 \\
\hline No & 352 & $7.6(6.9-8.2)$ & \\
\hline \multicolumn{4}{|l|}{ Annual income } \\
\hline$\$ 75,000$ or higher & 174 & $7.7(6.9-8.6)$ & .31 \\
\hline Less than $\$ 75,000$ & 221 & $8.17 .0-9.1)$ & \\
\hline \multicolumn{4}{|l|}{ Sex } \\
\hline Male & 136 & $6.4(5.5-7.4)$ & .001 \\
\hline Female & 259 & $8.7(7.8-9.6)$ & \\
\hline \multicolumn{4}{|l|}{ Race } \\
\hline White & 262 & $8.7(7.8-9.7)$ & .001 \\
\hline Nonwhite & 133 & $6.4(5.5-7.2)$ & \\
\hline \multicolumn{4}{|l|}{ Educational attainment } \\
\hline College or professional & 157 & $7.1(6.3-7.9)$ & .03 \\
\hline Some college or less & 238 & $8.5(7.4-9.5)$ & \\
\hline
\end{tabular}

cold rather than acute bronchitis, ${ }^{26}$ providing delayed prescriptions, ${ }^{27}$ using patient education leaflets, ${ }^{28}$ and emphasizing the distinction between bacteria and viruses (the CDC Get Smart: Know When Antibiotics Work campaign). ${ }^{29}$ We suggest that setting appropriate expectations should be an additional component of these efforts.

It is therefore important that physicians emphasize the natural history of $\mathrm{ACI}$ with patients when they seek care for an episode of acute cough. Patients should be told that it is normal to still be coughing 2 or even 3 weeks after onset, and that they should only seek care if they are worsening or if an alarm symptom, such as high fever, bloody or rusty sputum, or shortness of breath, occurs. Our survey confirmed that previous prescriptions of antibiotics increase the belief in their efficacy, creating the potential for a cycle of expectation and prescription.

We are unaware of data regarding physician knowledge of the natural history of $\mathrm{ACI}$, an area for future research. If physicians also underestimate its duration, they may require continuing professional education to correct these beliefs. Finally, sources that provide advice for patients regarding ACI should be updated to emphasize an expected duration of 2 to 3 weeks until symptoms are completely resolved, sometimes longer.

Limitations of the current study include those of any systematic review: our conclusions are only as valid as the available literature and the completeness and accuracy of study reports in the published literature. In particular, some studies did not report standard deviation for means, making it impossible to perform a more statistically appropriate random effects meta-analysis. The consistency of the mean duration of ACI in the included studies is reassuring, though, with none reporting a mean duration of less than 15 days. Because most of the included studies were from countries in temperate climates, the findings may not apply to tropical countries. The population-based survey is limited to adults in the state of Georgia and by the response rate; thus, it may not reflect beliefs or expectations regarding ACI and antibiotic use in other parts of the United States or in other countries. We are reassured by the diversity of our population in terms of age, race, sex, income, and educational 


\section{Table 4. Bivariate Analysis for Perceived Usefulness of Antibiotics}

\begin{tabular}{|c|c|c|c|c|}
\hline Variable & $\begin{array}{c}\text { Antibiotics } \\
\text { Always Helpful } \\
\text { No. (\%) }\end{array}$ & $\begin{array}{c}P \\
\text { Value }\end{array}$ & $\begin{array}{c}\text { Antibiotics Always } \\
\text { or Usually Helpful } \\
\text { No. (\%) }\end{array}$ & $\begin{array}{c}P \\
\text { Value }\end{array}$ \\
\hline \multicolumn{5}{|l|}{ Education } \\
\hline $\begin{array}{l}\text { College or professional } \\
\quad(n=191)\end{array}$ & $29(15.2)$ & & $73(38.2)$ & \\
\hline Other $(n=302)$ & $83(27.5)$ & .001 & $143(47.4)$ & .047 \\
\hline \multicolumn{5}{|l|}{ Income } \\
\hline$\geq \$ 75,000(n=208)$ & $39(18.7)$ & & $81(38.9)$ & \\
\hline$<\$ 75,000(n=285)$ & $73(25.6)$ & .072 & $135(47.4)$ & .063 \\
\hline \multicolumn{5}{|l|}{ Marital status } \\
\hline Married $(n=297)$ & $56(18.9)$ & & $124(41.7)$ & \\
\hline Other $(n=196)$ & $56(28.6)$ & .012 & $92(46.9)$ & .256 \\
\hline \multicolumn{5}{|l|}{ Race } \\
\hline White ( $n=330)$ & $64(19.4)$ & & $129(39.1)$ & \\
\hline Other $(n=163)$ & $48(29.5)$ & .012 & $87(53.4)$ & .003 \\
\hline \multicolumn{5}{|l|}{ Sex } \\
\hline Male $(n=182)$ & $45(24.7)$ & & $84(46.1)$ & \\
\hline Female $(n=311)$ & $67(21.5)$ & .416 & $132(42.4)$ & .423 \\
\hline \multicolumn{5}{|l|}{ Residence } \\
\hline Rural $(n=122)$ & $35(28.7)$ & & $55(45.1)$ & \\
\hline Other $(n=371)$ & $77(20.7)$ & .07 & $161(43.4)$ & .745 \\
\hline \multicolumn{5}{|l|}{$\begin{array}{l}\text { Self-reported asthma or } \\
\text { chronic lung disease }\end{array}$} \\
\hline Yes $(n=57)$ & $21(36.8)$ & & $29(50.9)$ & \\
\hline No $(n=436)$ & $91(20.9)$ & .007 & 187 (42.9) & .253 \\
\hline \multicolumn{5}{|l|}{$\begin{array}{l}\text { Self-reported any chronic } \\
\text { disease }\end{array}$} \\
\hline Yes $(n=209)$ & $47(22.5)$ & & $93(44.5)$ & \\
\hline No $(n=284)$ & $65(22.9)$ & .917 & $123(43.3)$ & .793 \\
\hline \multicolumn{5}{|l|}{$\begin{array}{l}\text { Previous antibiotic use for } \\
\text { respiratory tract infection }\end{array}$} \\
\hline Yes (n.= 287) & $78(27.2)$ & & $144(50.2)$ & \\
\hline No $(n=206)$ & $34(16.5)$ & .005 & $72(34.9)$ & .001 \\
\hline Age, y & $\begin{array}{c}54.6 \text { (always } \\
\text { helpful) vs } 56.6 \\
\text { (other) }\end{array}$ & .14 & $\begin{array}{c}55.5 \text { (always or } \\
\text { usually helpful) vs } \\
56.6 \text { (other) }\end{array}$ & .23 \\
\hline
\end{tabular}

Table 5. Logistic Regression With Antibiotics Always Effective and Antibiotics Always or Usually Effective as Dependent Variables

\begin{tabular}{lcc}
\hline Variable & $\begin{array}{c}\text { Antibiotics Always } \\
\text { Effective } \\
\text { OR }(95 \% \text { CI) }\end{array}$ & $\begin{array}{c}\text { Antibiotic Always } \\
\text { or Usually Effective } \\
\text { OR (95\% CI) }\end{array}$ \\
\hline Age & $0.99(0.98-1.01)$ & $1.00(0.99-1.01)$ \\
Married & $0.66(0.41-1.07)$ & $0.93(0.62-1.40)$ \\
Nonwhite & $1.82(1.14-2.94)^{\mathrm{a}}$ & $2.04(1.35-3.12)^{\mathrm{a}}$ \\
Male & $1.52(0.96-2.40)$ & $1.37(0.93-2.02)$ \\
Some college or less education & $2.08(1.26-3.45)^{\mathrm{a}}$ & $1.45(0.98-2.17)$ \\
Income $\geq \$ 75,000 / y$ & $0.90(0.55-1.48)$ & $0.78(0.52-1.16)$ \\
Self-reported asthma or chronic & $1.94(1.00-3.76)$ & $1.11(0.60-2.04)$ \\
$\quad$ lung disease & & $0.96(0.64-1.44)$ \\
Any chronic medical condition & $0.77(0.47-1.27)$ & $2.22(1.49-3.30)^{\mathrm{a}}$ \\
Self-reported previous antibiotic & $2.20(1.34-3.55)^{\mathrm{a}}$ & \\
$\quad$ use for ACl & & \\
\hline ACI $=$ acute cough illness; OR $=$ odds ratio. & & \\
a $P<.05$. & & \\
\hline
\end{tabular}

attainment, as well as the relatively good response rate for this kind of survey. In the survey we asked about the duration of acute cough illness; asking about the duration of the symptom of cough alone may have generated a different answer. Finally, that we found no statistically significant difference between expected durations of illness for the 6 vignettes may have been due to small sample size.

We found a large mismatch between patients' expectations regarding the duration of acute cough illness and its actual natural history based on a systematic review of the best available published evidence. We believe that education of the general public, the media, and physicians should emphasize appropriate expectations regarding the natural history of ACI in order to reduce inappropriate demands for antibiotics.

To read or post commentaries in response to this article, see it online at http://www.annfammed.orgl content/11/1/5.

Key words: anti-bacterial agents; drug resistance, bacterial; bronchitis; cough; natural history

Submitted April 9, 2012; submitted, revised, May 31, 2012; accepted June 7, 2012.

Funding support: The survey was supported by the Institute for Evidence-Based Health Professions Education at the University of Georgia, Athens, Georgia.

\section{References}

1. Schappert SM, Rechtsteiner EA. Ambulatory medical care utilization estimates for 2007. National Center for Health Statistics. Vital Health Stat. 2011;13(169).

2. Grijalva CG, Nuorti JP, Griffin MR. Antibiotic prescription rates for acute respiratory tract infections in US ambulatory settings. JAMA. 2009;302(7):758-766.

3. Hay AD, Wilson A, Fahey T, Peters TJ. The duration of acute cough in preschool children presenting to primary care: a prospective cohort study. Fam Pract. 2003;20(6):696-705. 
4. Hay AD, Wilson AD. The natural history of acute cough in children aged 0 to 4 years in primary care: a systematic review. $\mathrm{Br} J \mathrm{Gen}$ Pract. 2002;52(478):401-409.

5. Stott NCH, West RR. Randomised controlled trial of antibiotics in patients with cough and purulent sputum. Br Med J. 1976;2(6035):556-559.

6. Williamson HA Jr. A randomized, controlled trial of doxycycline in the treatment of acute bronchitis. J Fam Pract. 1984;19(4):481-486.

7. Brickfield FX, Carter WH, Johnson RE. Erythromycin in the treatment of acute bronchitis in a community practice. J Fam Pract. 1986;23(2):119-122

8. Dunlay J, Reinhardt R, Roi LDA. A placebo-controlled, double-blind trial of erythromycin in adults with acute bronchitis. J Fam Pract. 1987;25(2):137-141.

9. Scherl ER, Riegler SL, Cooper JK. Doxycycline in acute bronchitis: a randomized double-blind trial. J Ky Med Assoc. 1987;85(9):539-541.

10. Verheij TJM, Hermans J, Mulder JD. Effects of doxycycline in patients with acute cough and purulent sputum: a double blind placebo controlled trial. Br J Gen Pract. 1994;44(386):400-404.

11. Hueston WJ. Albuterol delivered by metered-dose inhaler to treat acute bronchitis. J Fam Pract. 1994;39(5):437-440.

12. King DE, Williams WC, Bishop L, Shechter A. Effectiveness of erythromycin in the treatment of acute bronchitis. J Fam Pract. 1996;42(6):601-605.

13. Littenberg $B$, Wheeler $M$, Smith DS. A randomized controlled trial of oral albuterol in acute cough. J Fam Pract. 1996;42(1):49-53.

14. Matthys H, de Mey C, Carls C, Rys A, Geib A, Wittig T. Effiacy and tolerability of myrtol standardized in acute bronchitis: a multicentre, randomised, double-blind, placebo-controlled parallel group trial vs cefuroxime and ambroxol. Arzneimmittelforschung. 2000;50(8):700-711.

15. Matthys $H$, Eisebitt R, Seith B, Heger M. Efficacy and safety of an extract of Pelargonium sidoides (EPs 7630) in adults with acute bronchitis. A randomised, double-blind, placebo-controlled trial. Phytomedicine. 2003;10(Suppl 4):7-17.

16. Chuchalin AG, Berman B, Lehmacher W. Treatment of acute bronchitis in adults with a Pelargonium sidoides preparation (EPs 7630): a randomized, double-blind, placebo-controlled trial. Explore (NY). 2005;1(6):437-445.

17. Little P, Rumsby K, Kelly J, et al. Information leaflet and antibiotic prescribing strategies for acute lower respiratory tract infection: a randomized controlled trial. JAMA. 2005;293(24):3029-3035.

18. Kemmerich B. Evaluation of efficacy and tolerability of a fixed combination of dry extracts of thyme herb and primrose root in adults suffering from acute bronchitis with productive cough. A prospective, double-blind, placebo-controlled multicentre clinical trial. [Drug Research]. Arzneimittelforschung. 2007;57(9):607-615.
19. Matthys $H$, Heger $M$. Treatment of acute bronchitis with a liquid herbal drug preparation from Pelargonium sidoides (EPs 7630): a randomised, double-blind, placebo-controlled, multicentre study. Curr Med Res Opin. 2007;23(2):323-331.

20. Nduba VN, Mwachari CW, Magaret AS, et al. Placebo found equivalent to amoxicillin for treatment of acute bronchitis in Nairobi, Kenya: a triple blind, randomised, equivalence trial. Thorax. 2008;63(11):999-1005.

21. Matthys H, Funk P. EPs 7630 improves acute bronchitic symptoms and shortens time to remission. Results of a randomised, double-blind, placebo-controlled, multicentre trial. Planta Med. 2008;74(6):686-692.

22. Matthys H, Lizogub VG, Malek FA, Kieser M. Efficacy and tolerability of EPs 7630 tablets in patients with acute bronchitis: a randomised, double-blind, placebo-controlled dose-finding study with a herbal drug preparation from Pelargonium sidoides. Curr Med Res Opin. 2010;26(6):1413-1422.

23. Butler CC, Hood K, Kelly MJ, et al. Treatment of acute cough/lower respiratory tract infection by antibiotic class and associated outcomes: a 13 European country observational study in primary care. J Antimicrob Chemother. 2010;65(11):2472-2478.

24. Wilson AA, Crane LA, Barrett PH, Gonzales R. Public beliefs and use of antibiotics for acute respiratory illness. J Gen Intern Med. 1999;14(11):658-662.

25. Cals JWL, Boumans D, Lardinois RJM, et al. Public beliefs on antibiotics and respiratory tract infections: an internet-based questionnaire study. Br J Gen Pract. 2007;57(545):942-947.

26. Phillips TG, Hickner J. Calling acute bronchitis a chest cold may improve patient satisfaction with appropriate antibiotic use. J Am Board Fam Pract. 2005;18(6):459-463.

27. Arroll B, Kenealy T, Kerse N. Do delayed prescriptions reduce the use of antibiotics for the common cold? A single-blind controlled trial. J Fam Pract. 2002;51(4):324-328.

28. Macfarlane J, Holmes W, Gard P, Thornhill D, Macfarlane R, Hubbard R. Reducing antibiotic use for acute bronchitis in primary care: blinded, randomised controlled trial of patient information leaflet. BMJ. 2002;324(7329):91-94.

29. Centers for Disease Control and Prevention. Get Smart campaign Web site. http://www.cdc.gov/getsmart/. Accessed Oct 30, 2011. 